\title{
Can fiberoptic bronchoscopy be applied to critically ill patients treated with noninvasive ventilation for acute respiratory distress syndrome? Prospective observational study
}

Pervin Korkmaz Ekren ${ }^{1 *}$, Burcu Basarik Aydogan', Alev Gurgun ${ }^{1}$, Mehmet Sezai Tasbakan ${ }^{1}$, Feza Bacakoglu and Stefano $\mathrm{Nava}^{2}$

\begin{abstract}
Background: Noninvasive ventilation (NIV) is a cornerstone for the treatment of acute respiratory failure of various etiologies. Using NIV is discussed in mild-to-moderate acute respiratory distress syndrome (ARDS) patients $\left(\mathrm{PaO}_{2} / \mathrm{FiO}_{2}>150\right)$. These patients often have comorbidities that increase the risk for bronchoscopy related complications. The primary outcome of this prospective observational study was to evaluate the feasibility, safety and contribution in diagnosis and/or modification of the ongoing treatment of fiberoptic bronchoscopy (FOB) in patients with ARDS treated with NIV.

Methods: ARDS patients treated with NIV and who require FOB as the diagnostic or therapeutic procedure were included the study. Intensive care ventilators or other dedicated NIV ventilators were used. NIV was applied via simple oro-nasal mask or full-face mask. Pressure support or inspiratory positive airway pressure (IPAP), external positive end expiratory pressure (PEEP) or expiratory positive airway pressure (EPAP) levels were titrated to achieve an expiratory tidal volume of 8 to $10 \mathrm{ml} / \mathrm{kg}$ according to ideal body weight, $\mathrm{SpO}_{2}>90 \%$ and respiratory rate below 25/min.

Results: Twenty eight subjects (mean age $63.3 \pm 15.9$ years, 15 men, 13 women, $\mathrm{PaO}_{2} / \mathrm{FiO}_{2}$ rate $145 \pm 50.1$ at admission) were included the study. Overall the procedure was well tolerated with only 5 (17.9\%) patients showing minor complications. There was no impairment in arterial blood gas and cardiopulmonary parameters after FOB. $\mathrm{PaO}_{2} / \mathrm{FiO}_{2}$ rate increased from $132.2 \pm 49.8$ to $172.9 \pm 63.2(p=0.001)$. No patient was intubated within $2 \mathrm{~h}$ after the bronchoscopy. 10.7, 32.1 and $39.3 \%$ of the patients required invasive mechanical ventilation after $8 \mathrm{~h}, 24 \mathrm{~h}$ and $48 \mathrm{~h}$, respectively. Bronchoscopy provided diagnosis in 27 (96.4\%) patients. Appropriate treatment was decided according to the results of the bronchoscopic sampling in 20 (71.4\%) patients.

Conclusion: FOB under NIV could be considered as a feasible tool for diagnosis and guide for treatment of patients with ARDS treated via NIV in intensive care units. However, FOB-correlated life-treathening complications in severe hypoxemia should not be forgotten. Furthermore, further controlled studies involving a larger series of homogeneous ARDS patients undergoing FOB under NIV are needed to confirm these preliminary findings.
\end{abstract}

Keywords: Bronchoscopy, Noninvasive ventilation, Acute respiratory distress syndrome, Diagnosis, Safety

\footnotetext{
* Correspondence: pervinkorkmaz@yahoo.com

'Department of Chest Disease, Ege University Medical Faculty, Bornova

35100, Izmir, Turkey

Full list of author information is available at the end of the article
} 


\section{Background}

Noninvasive ventilation (NIV) is defined as any form of ventilatory support applied without endotracheal intubation [1]. Application of NIV is a cornerstone for the treatment of acute respiratory failure of various etiologies [2]. It reduces intubation rate in patients with exacerbations of chronic obstructive pulmonary disease (COPD) and acute cardiogenic pulmonary edema [3] and in immunocompromised patients with hypoxemic respiratory failure $[4,5]$. Using NIV is discussed in mildto-moderate acute respiratory distress syndrome (ARDS) patients $\left(\mathrm{PaO}_{2} / \mathrm{FiO}_{2}>150\right)[6]$.

Fiberoptic bronchoscopy (FOB) may be required in some patients with acute respiratory failure in intensive care units (ICU), mainly as diagnostic tool or to remove abundant secretions [7, 8]. As a matter of fact it may also be applied to determine the cause of diffuse pulmonary infiltrates (infection, diffuse alveolar hemorrhage, organizing pneumonia) [9]. Other indications for FOB in critically ill patients consist of atelectasis, hemoptysis and suspicion of lung neoplasia. Patients in ICU for acute respiratory failure often have comorbidities that increase the risk of bronchoscopy related complications. Feasibility of bronchoscopy during NIV in patients with respiratory failure was shown previously and NIV was found to be superior to conventional oxygen supplementation for preventing gasexchange deterioration during FOB $[10,11]$. In those studies, NIV was used to facilitate bronchoscopy and NIV was not required prior to bronchoscopy. However, there is limited data on the feasibility and usefulness of FOB in patients who are already treated with NIV for acute respiratory failure [12] and in particular there is not enough evidence for using NIV in patients with ARDS [6]. Therefore, we aimed to evaluate the feasibility and safety of FOB in patients with ARDS ventilated with NIV and its contribution in the diagnosis and/or modification of the ongoing therapy.

\section{Methods}

The patients hospitalized in 8-bed ICU at Ege University Medical School Department of Chest Diseases were assessed in terms of ARDS, NIV treatment and FOB application. The decision both to initiate NIV and to perform FOB were made by the pulmonologist. This prospective observational study was approved by the Ege University Ethical and Research Project Committee (2010-TIP-088). All study participants or legal representatives provided written informed consent before the procedures.

\section{Study population}

The study population was obtained from the specified respiratory intensive care unit (January 2010-December 2014).
Inclusion criteria were: 1. ARDS diagnosed by Berlin criteria or The American-European Consensus Conference $[13,14], 2$. Age $\geq 18$ years, 3 . Treated with NIV before the bronchoscopy 4. Requiring FOB with or without bronchoalveolar lavage (BAL) for diagnostic or therapeutic apporach, 5. Informed consent. Exclusion criteria were: 1. Refusal of NIV, 2. Presence of contraindications for NIV such as facial deformity, upper gastrointestinal bleeding, upper airway obstruction, inability to protect the airway, significantly altered mental status, severe haemodynamic instability, respiratory or cardiac arrest and acute coronary syndromes, 3. Tracheostomy or intubation before admission, 4. Presence of contraindications for bronchoscopy procedure such as insufficient platelet number $(<70,000$ cells $/ \mu \mathrm{L})$ and coagulation disorders, 5. Patients with NIV use at home prior to ICU admission.

Demographic characteristics, comorbid diseases, presence of immunosuppression, Acute Physiology and Chronic Health Evaluation II (APACHE II) score [15] and radiologic and laboratory findings were recorded for each patient. Acquired immunodeficiency syndrome, immunosuppressive medication, organ transplantation, high dose chemotherapy during the past 60 days, absolute neutrophil count $<1000 / \mathrm{mL}$ were defined as immunosuppression. Standard microbiological diagnostic measures before FOB and additional serological studies were ordered in immunosuppressed patients as indicated. Heart and respiratory rates, blood pressures and arterial blood gases were assessed $15 \mathrm{~min}$ before and $1 \mathrm{~h}$ after the FOB for this study. These measurements and ventilator settings were monitored during FOB.

\section{Noninvasive ventilation}

All patients were on NIV prior and throughout the bronchoscopic sampling in the ICU. NIV was applied via simple oro-nasal mask (AF 531 Oro-nasal mask, Philips Respironics) or full-face mask (PerforMax Total face mask, Philips Respironics) (Fig. 1) and the ventilator settings were adjusted by the pulmonologist. ICU ventilator (Servo 900C, Siemens) or dedicated NIV ventilator (VIVO 40, General Electric) devices were set with the optimal required $\mathrm{FiO}_{2}$. Pressure support or inspiratory positive airway pressure (IPAP), external positive end expiratory pressure (PEEP) or expiratory positive airway pressure (EPAP) levels were titrated to achieve an expiratory tidal volume of 8 to $10 \mathrm{ml} / \mathrm{kg}$ according to ideal body weight, adjusted to maintain $\mathrm{SpO}_{2}>90 \%$ and respiratory rate below $25 / \mathrm{min}$.

\section{Bronchoscopy procedure}

Throughout the NIV treatment and bronchoscopy procedure electrocardiography, intra arterial blood pressure, pulse oximeter and ventilator parameters were monitored continuously. The ICU bronchoscopy team was 

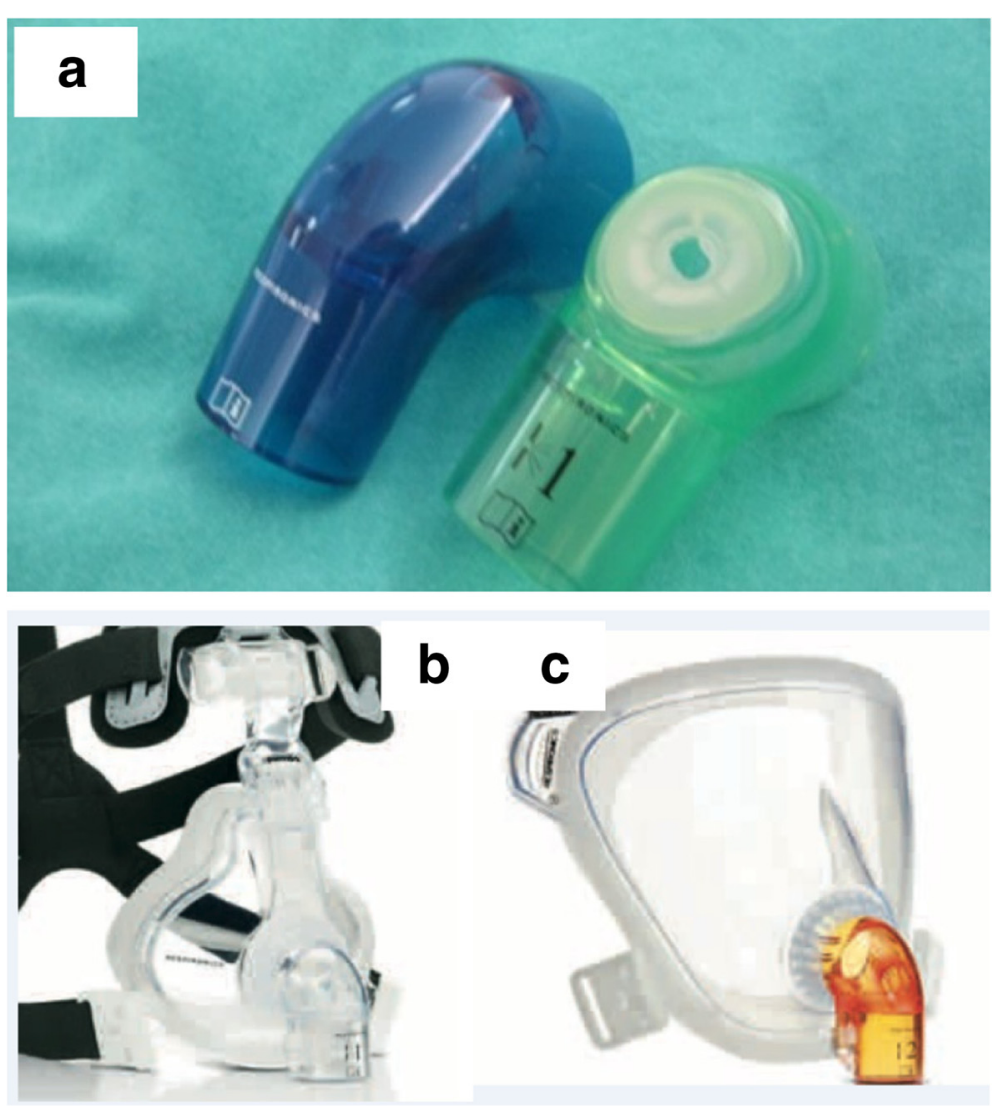

Fig. 1 a Used connector between the ventilator tubing and the mask for the insertion of FOB, b Oro-nasal mask, c Full-face mask

composed of two well-trained pulmonologists (FB, MST) and two nurses. All bronchoscopies were performed while patients were in upright position and in their own beds. $10 \%$ lidocaine spray solution and $2 \%$ lidocaine solution were used for topical anaesthesia of nasopharynx and tracheobronchial tree, respectively. A connector (bronchoscopy elbow, Philips Respironics) was used between the ventilator tubing and the mask for the insertion of FOB (Olympus BFU 180F) (Fig. 1). Fiberoptic bronchoscopy was performed via nasal route. Short term sedation was administered in some patients according to their respiratory and hemodynamic situations. Sedation was started using $2 \mathrm{mg}$ midazolam at the beginning of the procedure. The patients who did not achieve stabilisation received repetitive applications of 1 to $2 \mathrm{mg}$ midazolam. Maximum total dose of midazolam was $5 \mathrm{mg}$. Patients were supplied with the necessary $\mathrm{FiO}_{2}$ which provided $\mathrm{SpO}_{2}>90$ \% during $\mathrm{FOB}$ procedure (one or more of these procedures were performed in same FOB application: BAL, bronchoscopic brushings and biopsy, aspiration) under NIV. The bronchoscopic samples were sent to microbiology and pathology laboratories. Antimicrobial treatment was started empirically while the sampling was performed and, later treatment was adjusted according to microbiological results.

\section{Outcomes}

Primary outcomes were: 1 . Safety with the recording of any complications [such as fever, arrhythmia, hypoxemia $\left(\mathrm{SpO}_{2}\right.$ $<90 \%$ ), hypotension (systolic and diastolic blood pressure below $90 \mathrm{mmHg}$ and $60 \mathrm{mmHg}$, respectively), haemorrhage and pneumothorax]. 2. Contribution of FOB in diagnosis and/or modification of the ongoing treatment. 3. Requirement for endotracheal intubation was specifically observed within two hours and eight hours after the FOB. Criteria of two and eight hour limit for endotracheal intubation were adopted from previous studies $[16,17]$.

\section{Data analyses}

Data management and analysis of all data were conducted via SPSS for Windows 16.0 software (SPSS, version 16, Chicago). Kolmogorov-Smirnov test was used to present the distribution of all recorded variables. Arterial blood gases and haemodynamic parameters before and after FOB were compared with Wilcoxon test. Statistical significance level was set at $p<0.05$. 


\section{Results}

\section{Patient characteristics}

Twenty eight subjects (mean age $63.3 \pm 15.9$ years, 15 men, 13 women) were included the study. 20 patients (71.4 \%) had immunosuppression. Patients had hematologic malignancy, solid-organ tumor, renal transplantation, long-term corticosteroid treatment due to interstitial lung disease or connective tissue disease that caused immunosuppression. The most common admission diagnosis to ICU was pneumonia (Table 1). As shown on Table 2, FOB indications were: suspicion of opportunistic infections in 18 patients $(64.3 \%)$, alveolar hemorrhage in 4 patients (14.3\%), suspicion of malignancy in 4 patients (14.3\%), aspiration as therapeutic approach in 4 patients $(14.3 \%)$ and other indications were exacerbation of idiopathic pulmonary fibrosis, drug induced pulmonary toxicity and pulmonary involvement of rheumatoid arthritis. Fiberoptic bronchoscopy was performed with ICU ventilator in $82.1 \%$ of patients and dedicated NIV ventilators were used for the remaining patients. $\mathrm{PaO}_{2} / \mathrm{FiO}_{2}$ ratio before FOB application was calculated as $132.2 \pm 49.8$. Twenty three $(82.1 \%)$ patients received $100 \% \mathrm{FiO}_{2}$ during $\mathrm{FOB}$ to

Table 1 Patient characteristics at admission $(n=28)$

\begin{tabular}{ll}
\hline Age (yrs) & $63.3 \pm 15.9$ \\
Gender (male), $n$ (\%) & $15(53.6)$ \\
Comorbid illnesses, $n$ (\%) & $27(96.4)$ \\
Coronary artery disease & $9(32.1)$ \\
Hematological malignancy & $7(25.0)$ \\
Interstitial lung disease & $6(21.4)$ \\
Connective tissue diseases & $6(21.4)$ \\
Chronic lung disease & $5(17.9)$ \\
Solid organ malignancy & $4(14.3)$ \\
Diabetes mellitus & $3(10.7)$ \\
Chronic renal failure & $3(10.7)$ \\
Others & $3(10.7)$ \\
Immunosuppression, $n$ (\%) & $20(71.4)$ \\
APACHE $\|$ score ${ }^{a}$ & $15.5(9-27)$ \\
PaO ${ }_{2}$ FiO 2 & $145 \pm 50.1$ \\
The diagnosis of hospitalisation, $n$ (\%) & \\
Pneumonia & \\
Alveoler hemorrhage & $20(71.4)$ \\
Respiratory failure (other etiology) & $3(10.7)$ \\
ARDS, $n$ (\%) & $5(17.9)$ \\
Mild & \\
Moderate & $5(17.9)$ \\
Severe & \\
Bilatateral & \\
\hline
\end{tabular}

${ }^{\text {a Median value (range) }}$

Abbreviations: APACHE I/ acute physiology assessment and chronic health evaluation II, ARDS acute respiratory distress syndrome allow $\mathrm{SpO}_{2}$ levels which must be achieved above $90 \%$. Pressure support, IPAP and EPAP/PEEP values during FOB were 9 (0-18), $20(8-28)$ and $8(5-12) \mathrm{cmH}_{2} \mathrm{O}$, respectively.

\section{Tolerance and safety of fiberoptic bronchoscopy}

The median duration of NIV prior to FOB was $3 \mathrm{~h}$ (range 0-72 h). Vasopressor/inotropic agents before the FOB application were begun in 4 patients $(14.3 \%)$ due to hemodynamic instability. Thirteen patients $(46.4 \%)$ received sedation for NIV and/or FOB. Maximum duration of the bronchoscopy was $20 \mathrm{~min}$ and FOB application was performed only once for each patients. Arterial blood gas analyses, $\mathrm{PaO}_{2} / \mathrm{FiO}_{2}$ rates and cardiorespiratory parameters before and after FOB were shown in Table 3. There was no impairment in these parameters after bronchoscopy. $\mathrm{PaO}_{2} / \mathrm{FiO}_{2}$ rate increased from $132.2 \pm 49.8$ to 172.9 \pm 63.2 after procedure. Pressure support, IPAP, EPAP/ $\mathrm{PEEP}$ and $\mathrm{FiO}_{2}$ levels did not change during $\mathrm{FOB}$.

Respiratory and hemodynamic variables were followed up very closely for the required intubation. Complications other than endotracheal intubation developed in $5(17.9 \%)$ patients within $12 \mathrm{~h}$ after FOB. Fever $(n=2)$, hypoxemia $(n=1)$ and hypotension $(n=$ 2 ) occurred as complication of bronchoscopy. In one of these patients, hypotension developed within the first four hours. No other adverse effects were observed such as haemorrhage and pneumothorax.

Endotracheal intubation was not required within $2 \mathrm{~h}$ after the bronchoscopy. Intubation was performed only in three patients $(10.7 \%)$ within $8 \mathrm{~h}$. Two of them had severe coinfection with Cytomegalovirus and Pneumocystis jiroveci. 32.1 and $39.3 \%$ of the patients required IMV within $24 \mathrm{~h}$ and $48 \mathrm{~h}$, respectively. Due to deterioration of respiratory failure or septic shock, 6 patients $(21.4 \%)$ were intubated after $48 \mathrm{~h}$ of the procedure. Five of them had hospital acquired infection in their follow ups.

\section{Clinical usefulness of fiberoptic bronchoscopy} Bronchoscopy contributed to diagnosis of 27 (96.4 \%) patients. Bacteria $(n=2)$, fungus $(n=18)$, cytomegalovirus $(n=12)$, other viruses $(n=5)$ and M. tuberculosis $(n=1)$ were isolated in $23(82.1 \%)$ patients as underlying infectious agent. Candida spp. was accepted as cause of infection for 6 patients, because 3 patients were immunosuppressive and we found no other etiologic opportunistic infection agents in the remaining patients. Various combinations of the infectious agents were shown in 12 (42.9\%) patients. Alveolar hemorrhage was diagnosed in 4 patients and malignancy was reported as a result of cytologic examination in 2 patients. While secretions were being removed in 3 patients, atelectasis was resolved in one patient by FOB. Appropriate 
Table 2 Patients characteristics, indications and results of FOB

\begin{tabular}{|c|c|c|c|c|c|c|c|c|}
\hline No & $\begin{array}{l}\text { Diagnosis at } \\
\text { hospitalisation }\end{array}$ & Immuno-suppression & $\begin{array}{l}\text { PreFOB ARDS } \\
\text { category }\end{array}$ & FOB indications & $\begin{array}{l}\text { FOB } \\
\text { diagnosis }\end{array}$ & Infectious agents & Intubation & $\begin{array}{l}\text { Intubation } \\
\text { time (hour) }\end{array}$ \\
\hline 1 & Pneumonia & + & Severe & Opportunistic infections & Infection & CMV & - & \\
\hline 2 & Pneumonia & + & Mild & Opportunistic infections & Infection & Geotrichum capitatum & + & $24-48$ \\
\hline 3 & Pneumonia & - & Severe & Opportunistic infections & Infection & $\begin{array}{l}\text { Aspergillus spp., } \\
\text { Respiratory virus }\end{array}$ & - & \\
\hline 4 & Pneumonia & + & Mild & Opportunistic infections & Infection & $\begin{array}{l}\text { C. albicans, CMV, } \\
\text { Respiratory virus }\end{array}$ & - & \\
\hline 5 & Pneumonia & + & Moderate & Opportunistic infections & Infection & C. albicans, CMV & - & \\
\hline 6 & $\begin{array}{l}\text { Alveoler } \\
\text { hemorrhage }\end{array}$ & + & Moderate & Alveoler hemorrhage & $\begin{array}{l}\text { Alveoler } \\
\text { hemorrhage }\end{array}$ & & - & \\
\hline 7 & Respiratory failure & - & Moderate & Aspiration & Infection & Non-albicans Candida & + & $>48$ \\
\hline 8 & Pneumonia & + & Severe & Alveoler hemorrhage & $\begin{array}{l}\text { Alveoler } \\
\text { hemorrhage }\end{array}$ & CMV & + & $8-24$ \\
\hline 9 & Respiratory failure & - & Moderate & Aspiration & Infection & $\begin{array}{l}\text { CMV, Aspergillus spp., } \\
\text { C. albicans }\end{array}$ & + & $>48$ \\
\hline 10 & Pneumonia & - & Moderate & Malignancy & Infection & K. pneumoniae, CMV & - & \\
\hline 11 & Pneumonia & - & Mild & Malignancy & Infection & C. albicans & + & $8-24$ \\
\hline 12 & Pneumonia & + & Moderate & Opportunistic infections & Infection & $C M V, P C P$ & + & $<8$ \\
\hline 13 & Pneumonia & - & Severe & Opportunistic infections & Infection & CMV, C. albicans & - & \\
\hline 14 & Pneumonia & - & Severe & Aspiration & Infection & C. albicans & + & $8-24$ \\
\hline 15 & $\begin{array}{l}\text { Alveoler } \\
\text { hemorrhage }\end{array}$ & + & Moderate & Alveolar hemorrhage & Infection & C. albicans & - & \\
\hline 16 & Respiratory failure & + & Moderate & Opportunistic infections & Infection & $C M V, P C P$ & + & $<8$ \\
\hline 17 & Pneumonia & + & Moderate & Opportunistic infections & $\begin{array}{l}\text { Alveoler } \\
\text { hemorrhage }\end{array}$ & & - & \\
\hline 18 & Respiratory failure & + & Mild & Opportunistic infections & Infection & C. albicans & + & $24-48$ \\
\hline 19 & Pneumonia & + & Moderate & Opportunistic infections & $\begin{array}{l}\text { Malignancy } \\
\text { Infection }\end{array}$ & P. aeruginosa & + & $8-24$ \\
\hline 20 & Respiratory failure & + & Severe & Opportunistic infections & Infection & $\begin{array}{l}\text { C. albicans, Respiratory } \\
\text { viruses }\end{array}$ & - & \\
\hline 21 & Pneumonia & - & Moderate & Aspiration & - & & + & $8-24$ \\
\hline 22 & $\begin{array}{l}\text { Alveoler } \\
\text { hemorrhage }\end{array}$ & + & Severe & Alveoler hemorrhage & $\begin{array}{l}\text { Alveoler } \\
\text { hemorrhage }\end{array}$ & & - & \\
\hline 23 & Pneumonia & + & Severe & Multiple etiologies ${ }^{a}$ & Infection & Acremonium, CMV & + & $<8$ \\
\hline 24 & Pneumonia & + & Moderate & Multiple etiologies ${ }^{\mathrm{b}}$ & Infection & $\begin{array}{l}\text { C. albicans, Respiratory } \\
\text { viruses, CMV }\end{array}$ & + & $>48$ \\
\hline 25 & Pneumonia & + & Severe & Multiple etiologies ${ }^{c}$ & Infection & $\begin{array}{l}\text { Acremonium, Aspergillus } \\
\text { spp., Respiratory viruses, } \\
\text { CMV }\end{array}$ & + & $>48$ \\
\hline 26 & Pneumonia & + & Moderate & Opportunistic infections & Infection & C. albicans & + & $8-24$ \\
\hline 27 & Pneumonia & + & Severe & Multiple etiologies ${ }^{d}$ & Malignancy & & + & $>48$ \\
\hline 28 & Pneumonia & + & Moderate & Opportunistic infections & Infection & M. tuberculosis & + & $>48$ \\
\hline
\end{tabular}

Abbrevations: $C M V$ cytomegalovirus, PCP Pneumocystis jiroveci pneumonia

apportunistc infections, exacerbation of idiopathic pulmonary fibrosis

${ }^{\mathrm{b}}$ Malignancy, alveoler hemorrhage, opportunistic infections, drug induced pulmonary toxicity

'Pulmonary involvement of rheumatoid arthritis, opportunistic infections, drug induced pulmonary toxicity

${ }^{\mathrm{d} O p p o r t u n i s t c ~ i n f e c t i o n s, ~ m a l i g n a n c y ~}$

treatment was arranged in 20 patients $(71.4 \%)$ according to FOB results. Initial empirical treatments were appropriate in the remaining patients.

\section{Discussion}

The study demonstrated that bronchoscopy under NIV is feasible, safe and an effective diagnostic procedure, 
Table $\mathbf{3}$ Hemodynamic and arterial blood gas parameters before and after FOB

\begin{tabular}{llll}
\hline Parameters & Before FOB & After FOB & $p$ value \\
\hline Arterial blood gas & & & \\
$\mathrm{pH}$ & $7.45 \pm 0.12$ & $7.36 \pm 0.14$ & 0.07 \\
$\mathrm{PaCO}_{2}(\mathrm{mmHg})$ & $41.3 \pm 15.6$ & $41.7 \pm 16.1$ & 0.56 \\
$\mathrm{PaO}_{2} / \mathrm{FiO}_{2}$ & $132.2 \pm 49.8$ & $172.9 \pm 63.2$ & $\mathbf{0 . 0 0 1}$ \\
Mean arterial pressure $(\mathrm{mmHg})$ & $96.7 \pm 18.8$ & $94.3 \pm 19.6$ & 0.43 \\
Heart rate/min & $104.0 \pm 20.1$ & $102.1 \pm 18.6$ & 0.48 \\
\hline
\end{tabular}

The number in boldface reflects $p<0.05$

therapeutic approach and guide for treatment in ARDS patients. After the procedure, arterial blood gas values, $\mathrm{PaO}_{2} / \mathrm{FiO}_{2}$ rate, and cardiac parameters did not change and none of the patients needed intubation within two hours after bronchoscopy. Fiberoptic bronchoscopy can be performed safely without major complications in this group of patients.

Diagnostic or therapeutic bronchoscopy is necessary for some ICU patients treated for acute respiratory failure, however it can be associated with various complications as well as mortality. Because of these risks, FOB can be challenging in these patients. Bronchoscope covers $10-15 \%$ of the tracheal lumen and may increase respiration efforts and decrease $\mathrm{PaO}_{2}$ by $10-20 \mathrm{mmHg}$ causing respiratory and cardiac complications [18]. Additionally, BAL sampling may cause worsening of oxygen desaturation [19]. The American Thoracic Society recommends avoiding $\mathrm{FOB}$ and $\mathrm{BAL}$ in patients with hypoxemia $\left(\mathrm{PaO}_{2}<75 \mathrm{mmHg}\right.$ or oxygen saturation $<90 \%$ with supplemental oxygen) [20]. Although alternative approaches in these patients with higher-risk are empirical treatments or intubation for FOB, the observational study and the randomized controlled trials have shown that NIV may be an alternative to endotracheal intubation in these critically ill patients who are not previously ventilated $[10,11,21]$.

Early etiological diagnosis in critically ill patients is important for appropriate treatment. Baumann et al. [12] showed that BAL during NIV yielded diagnostic information in $68 \%$ of the patients with acute respiratory failure. Diagnostic success of FOB was $59 \%$ in another study in which oxygen supplementation or NIV application was used during the procedure [22]. Our immunosuppressed patient ratio was higher than the study population of Bauman et al. and Cracco et al. (71.4 \% vs $53 \%, 53 \%$, respectively). Clouzeau et al. [16] found that diagnostic or therapeutic information ratio was $75 \%$ in patients who underwent FOB under NIV. $83.3 \%$ of their patients were immunocompromise. In our study, diagnostic accuracy of FOB in ARDS patients was $96.4 \%$. High diagnostic rate in our study can be interpreted with the fact that we performed sampling with FOB just as the patients apply to ICU. At the same time, FOB application allowed the therapeutic approaches such as aspiration. Furthermore, Agarwal et al. [23] have shown that NIV-assisted bronchoscopic lung biopsy is another diagnostic method in hypoxemic patients with diffuse lung infiltrates.

Azoulay et al. [24] found that deterioration in respiratory status occurred in $44.8 \%$ of patients who had BAL with oxygen. But only $18.7 \%$ of their patients underwent BAL with NIV. Chiner et al. [21] showed that there were no significant differences in arterial blood gas levels in patients with acute respiratory failure before FOB and $2 \mathrm{~h}$ after FOB. Another study showed a significant improvement in arterial blood gas levels of patients with acute decompensated COPD due to community-acquired pneumonia second hour after FOB with NIV [25]. Secretion aspiration might lead to improvement. In our study, there were no significant changes in arterial blood gas analyses and cardiac parameters after FOB. Other complications such as cardiac arrhythmia, pneumothorax or hemoptysis did not occur in our study population.

Only three patients $(10.7 \%)$ were intubated within $8 \mathrm{~h}$ after FOB ( $5 \mathrm{~h}, 7 \mathrm{~h}$ and $8 \mathrm{~h}$, respectively). Underlying diseases of these patients were interstitial lung disease and lung involvement due to connective tissue disease. The patients were receiving systemic corticosteroid therapy before admission to hospital and FOB was applied to diagnose opportunistic infections. Three patients died within $24 \mathrm{~h}$ after the procedure. FOB should not be considered in these cases, because they had severe underlying diseases and infections when they were admitted. Identified mixt infectious agents had a major effect in their fast progression. Cytomegalovirus and Pneumocystis jiroveci in two patients, Acremonium and Cytomegalovirus in another patient were shown as opportunistic infectious agents. Fiberoptic bronchoscopy usually causes alteration in gas exchange. In hypoxemic intubated patients, $\mathrm{PaO}_{2}$ returns to baseline within $2 \mathrm{~h}$ [26]. None of the patients in the current study needed intubation within $2 \mathrm{~h}$ after FOB. Based on this information, FOB may not have led to intubation in three patients. Baumann et al. [12] found that 40 patients required NIV prior to the decision to use FOB. Four of them (10\%) required IMV within $8 \mathrm{~h}$. Within $48 \mathrm{~h}, 45 \%$ of their patients were intubated. In Baumann et al.'s study, mean baseline $\mathrm{PaO}_{2} / \mathrm{FiO}_{2}$ value was $176 \pm 54$ which is higher than the values of the current study. In the current study 10.7, 32.1 and $39.3 \%$ of patients required IMV within $8 \mathrm{~h}, 24 \mathrm{~h}$ and $48 \mathrm{~h}$, respectively. Clouzeau et al. [16] assessed BAL application under NIV in which $\mathrm{PaO}_{2} /$ $\mathrm{FiO}_{2}$ of their patients was $181 \pm 50$ before FOB. None of the patients was intubated within $2 \mathrm{~h}$, four of 23 patients (17.4 \%) were required IMV within $24 \mathrm{~h}$ after the procedure. Presence of the COPD and immunosuppression were 
shown as risk factors for intubation [22]. Intubation rate in the current study is acceptable according to presented rates in the literature. Intubation rate reached to $54 \%$ in patients with acute respiratory failure who received NIV. Also, NIV failure ratio was $62 \%$ in moderate and $84 \%$ in severe ARDS [27]. Cases in the current study were not intubated due to sudden gas exchanges and hemodynamic deterioration after bronchoscopy. Severe underlying diseases and infection situations should be taken into consideration for IMV.

The authors of this study aware of the discussions about using NIV in patients with ARDS. But a recent study which assessed intubation rate and risk factors of NIV failure in patients with non-hypercapnic acute hypoxemic respiratory failure showed significant differences for intubation rate among four groups (non-ARDS, mild ARDS, moderate ARDS, severe ARDS). However, the mortality rate was not statistically significant and the time to intubation had no effect on patient mortality [27]. In patients with hematologic malignancies and acute respiratory failure, delayed (after NIV failure) vs. immediate IMV was associated with increased hospital mortality which was not statistically significant (65 \% vs. $58 \%$ [28]. Early diagnosis and beginning time of true treatment in patients with immunosuppression may be as important as ARDS severity. The authors think that FOB under NIV treatment due to ARDS may be applied to patients whose $\mathrm{PaO}_{2} / \mathrm{FiO}_{2}$ ratio is close to 100 when their hemodynamic status is stable and procedure is performed in ICU where all intubation equipment for emergency intubation exist.

This study has some limitations. First, there are no control groups. Enrolment of a control group was not possible due to ethical reasons, because treatment with NIV requires in patients with acute respiratory failure. In other words, it is believed that intubation is not advisable solely for FOB applications. Second, the study population in the current study was small. Third, the study population was composed of patients with hypoxemic and hypercapnic respiratory failure. Fourth, the data about excluded patients was not given and limited number arterial blood gas analyses were assessed after FOB. Fifth, these results were from a single center.

\section{Conclusions}

In conclusion, FOB under NIV may be safely and effectively applied for diagnosis and treatment of patients with ARDS in ICU units that is adequately equipped and staffed for intubation. There are high risks associated with intubation during FOB and after procedure. Therefore, these patients should be closely followed up for ventilation and for other vital parameters. FOB with NIV may be considered in patients with ARDS for diagnosis and treatment, so intubation and its complications may be avoided in this patient group. More studies with large sample sizes are required to make a more thorough assessment of FOB application under NIV in patients with ARDS.

\section{Abbreviations \\ APACHE II: Acute Physiology and Chronic Health Evaluation II; ARDS: acute respiratory distress syndrome; BAL: bronchoalveolar lavage; COPD: chronic obstructive pulmonary disease; EPAP: expiratory positive airway pressures; FOB: fiberoptic bronchoscopy; ICU: intensive care unit; IPAP: inspiratory positive airway pressure; NIV: noninvasive ventilation; PEEP: positive end expiratory pressure.}

\section{Availability of data and materials}

The dataset of this article are stored in Department of Chest Diseases of Ege University Medical Faculty and can be made available upon request.

\section{Authors' contributions}

PKE participated in the design of the study, performed the statistical analysis and was the largest contributor to the manuscript. BBA was involved in drafting the manuscript and the acquisition of the data. FB was the main designer of this study and revised the manuscript critically for important intellectual content. MST participated in the design of this study. AG was one of the designers of this study and was involved in drafting the manuscript. SN was the other main designer of this study and revised the manuscript critically for important intellectual content. All authors have read and approved the final manuscript.

\section{Competing interests}

The authors except SN declare no conflict of interest. SN has conflict of interest: Advisory board for Philips and Breas, speaking fee from Philips and Resmed, travel grants from Weinman.

\section{Consent for publication}

Not applicable.

\section{Ethics approval and consent to participate}

This study was approved by the Ege University Ethical and Research Project Committee (2010-TIP-088).

\section{Author details}

${ }^{1}$ Department of Chest Disease, Ege University Medical Faculty, Bornova 35100, Izmir, Turkey. ${ }^{2}$ Department of Specialistic, Diagnostic and Experimental Medicine, Respiratory and Critical Care, Sant'Orsola Malpighi Hospital, Alma Mater Studiorum, University of Bologna, Bologna, Italy.

Received: 29 January 2016 Accepted: 1 May 2016

Published online: 31 May 2016

\section{References}

1. Organized jointly by the American Thoracic Society, the European Respiratory Society, the European Society of Intensive Care Medicine, and the Société de Réanimation de Langue Française, and approved by ATS Board of Directors, December 2000. International Consensus Conferences in Intensive Care Medicine: noninvasive positive pressure ventilation in acute Respiratory failure. Am J Respir Crit Care Med. 2001;163(1):283-91.

2. Nava S, Hill N. Non-invasive ventilation in acute respiratory failure. Lancet. 2009;374(9685):250-9.

3. Masip J, Roque M, Sánchez B, Fernández R, Subirana M, Expósito JA. Noninvasive ventilation in acute cardiogenic pulmonary edema: systematic review and meta-analysis. JAMA. 2005:294(24):3124-30.

4. Hilbert G, Gruson D, Vargas F, Valentino R, Gbikpi-Benissan G, Dupon M, Reiffers J, Cardinaud JP. Noninvasive ventilation in immunosuppressed patients with pulmonary infiltrates, fever, and acute respiratory failure. $\mathrm{N}$ Engl J Med. 2001;344(7):481-7.

5. Depuydt PO, Benoit DD, Vandewoude KH, Decruyenaere JM, Colardyn FA. Outcome in noninvasively and invasively ventilated hematologic patients with acute respiratory failure. Chest. 2004;126(4):1299-306. 
6. Rittayamai N, Brochard L. Recent advances in mechanical ventilation in patients with acute respiratory distress syndrome. Eur Respir Rev. 2015;24(135):132-40.

7. Ambrosino N, Guarracino F. Unusual applications of noninvasive ventilation. Eur Respir J. 2011;38(2):440-9.

8. Disdier C. Broncoscopia con soporte ventilatorio mecánico no invasivo. In: Esquinas Rodríguez AM, editor. Tratado de ventilación mecánica no invasiva. Práctica clínica y metodológica. Madrid: Grupo Aula Médica; 2006. p. 429-31.

9. Confalonieri M, Potena A, Carbone G, Porta RD, Tolley EA, Umberto MG. Acute respiratory failure in patients with severe community-acquired pneumonia. A prospective randomized evaluation of non-invasive ventilation. Am J Respir Crit Care Med. 1999;160(5 Pt 1):1585-91.

10. Antonelli M, Conti G, Rocco M, Arcangeli A, Cavaliere F, Proietti R, Meduri GU. Noninvasive positive-pressure ventilation vs. conventional oxygen supplementation in hypoxemic patients undergoing diagnostic bronchoscopy. Chest. 2002;121(4):1149-54.

11. Maitre B, Jaber S, Maggiore SM, Bergot E, Richard JC, Bakthiari H, Housset B, Boussignac G, Brochard L. Continuous positive airway pressure during fiberoptic bronchoscopy in hypoxemic patients. A randomized double-blind study using a new device. Am J Respir Crit Care Med. 2000;162(3 Pt 1):1063-7.

12. Baumann HJ, Klose H, Simon M, Ghadban T, Braunse SA, Hennigs JK, Kluge $S$. Fiber optic bronchoscopy in patients with acute hypoxemic respiratory failure requiring noninvasive ventilation - a feasibility study. Crit Care. 2011;15(4):R179.

13. Definition Task Force ARDS, Ranieri VM, Rubenfeld GD, Thompson BT, Ferguson ND, Caldwell E, Fan E, Camporota L, Slutsky AS. Acute respiratory distress syndrome: the Berlin definition. JAMA. 2012;307(23):2526-33.

14. Bernard GR, Artigas A, Brigham KL, Carlet J, Falke K, Hudson L, Lamy M, Legall JR, Morris A, Spragg R. The American-European Consensus Conference on ARDS. Definitions, mechanisms, relevant outcomes, and clinical trial coordination. Am J Respir Crit Care Med. 1994;149(3 Pt 1):818-24.

15. Knaus WA, Draper EA, Wagner DP, Zimmerman II JEAPACHE. A severity of disease classification system. Crit Care Med. 1985;13(10):818-29.

16. Clouzeau B, Bui HN, Guilhon E, Grenouillet-Delacre M, Leger MS, Saghi T, Pillot J, Filloux B, Coz S, Boyer A, et al. Fiberoptic bronchoscopy under noninvasive ventilation and propofol target-controlled infusion in hypoxemic patients. Intensive Care Med. 2011;37(12):1969-75.

17. Matsumoto T, Sato Y, Fukuda S, Katayama S, Miyazaki Y, Ozaki M, Kotani T. Safety and efficacy of bronchoalveolar lavage using a laryngeal mask airway in cases of acute hypoxaemic respiratory failure with diffuse lung infiltrates. Intern Med. 2015;54(7):731-5.

18. Payne Jr CB, Goyal PC, Gupta SC. Effects of transoral and transnasal fiberoptic bronchoscopy on oxygenation and cardiac rhythm. Endoscopy. 1986;18(1):1-3.

19. Katz AS, Michelson EL, Stawicki J, Holford FD. Cardiac arrhythmias. Frequency during fiberoptic bronchoscopy and correlation with hypoxemia. Arch Intern Med. 1981;141(5):603-6.

20. Goldstein RA, Rohatgi PK, Bergofsky EH, Block ER, Daniele RP, Dantzker DR, Davis GS, Hunninghake GW, King TE Jr, Metzger WJ, et al. Clinical role of bronchoalveolar lavage in adults with pulmonary disease. Am Rev Respir Dis. 1990;142(2):481-6.

21. Chiner E, Sancho-Chust JN, Llombart M, Senent C, Camarasa A, Signes-Costa J. Fiberoptic bronchoscopy during nasal non-invasive ventilation in acute respiratory failure. Respiration. 2010;80(4):321-6.

22. Cracco C, Fartoukh M, Prodanovic H, Azoulay E, Chenivesse C, Lorut C, Beduneau G, Bui HN, Taille C, Brochard L, et al. Safety of performing fiberoptic bronchoscopy in critically ill hypoxemic patients with acute respiratory failure. Intensive Care Med. 2013;39(1):45-52.

23. Agarwal R, Khan A, Aggarwal AN, Gupta D. Bronchoscopic lung biopsy using noninvasive ventilatory support: case series and review of literature of NIV-assisted bronchoscopy. Respir Care. 2012;57(11):1927-36.

24. Azoulay E, Mokart D, Rabbat A, Pene F, Kouatchet A, Bruneel F, Vincent F, Hamidfar R, Moreau D, Mohammedi I, et al. Diagnostic bronchoscopy in hematology and oncology patients with acute respiratory failure: prospective multicenter data. Crit Care Med. 2008;36(1):100-7.

25. Scala R, Naldi M, Maccari U. Early fiberoptic bronchoscopy during noninvasive ventilation in patients with decompensated chronic obstructive pulmonary disease due to community-acquired-pneumonia. Crit Care. 2010;14(2):R80

26. Trouillet JL, Guiguet M, Gibert C, Fagon JY, Dreyfuss D, Blanchet F, Chastre J. Fiberoptic bronchoscopy in ventilated patients. Evaluation of cardiopulmonary risk under midazolam sedation. Chest. 1990;97(4):927-33.
27. Thille AW, Contou D, Fragnoli C, Córdoba-Izquierdo A, Boissier F, BrunBuisson C. Non-invasive ventilation for acute hypoxemic respiratory failure: intubation rate and risk factors. Crit Care. 2013;17(6):R269.

28. Gristina GR, Antonelli M, Conti G, Ciarlone A, Rogante S, Rossi C, Bertolini G. GiViTI (Italian Group for the Evaluation of Interventions in Intensive Care Medicine). Noninvasive versus invasive ventilation for acute respiratory failure in patients with hematologic malignancies: a 5-year multicenter observational survey. Crit Care Med. 2011;39(10):2232-9.

\section{Submit your next manuscript to BioMed Central and we will help you at every step:}

- We accept pre-submission inquiries

- Our selector tool helps you to find the most relevant journal

- We provide round the clock customer support

- Convenient online submission

- Thorough peer review

- Inclusion in PubMed and all major indexing services

- Maximum visibility for your research

Submit your manuscript at www.biomedcentral.com/submit

) Biomed Central 